\title{
The Power of Bankruptey Courts to Shift Fees under the Equal Access to Justice Act
}

\author{
Charles R. Haywood $\dagger$
}

Statutory shifting of attorneys' fees ${ }^{1}$ has increasingly edged into the public eye, pushed by former Vice President Quayle's promotion of fee shifting as the central pillar of his civil justice reform proposals. ${ }^{2}$ Despite its newfound popularity as a political football, fee shifting by statute has a long history in the federal system. The most prominent development is the Equal Access to Justice Act ("EAJA"), which helps citizens litigate meritorious cases against the United States by reimbursing them for their legal fees if they prevail. ${ }^{3}$ This Comment focuses on the scope of this enablement: did Congress extend fee-shifting authority to bankruptcy courts?

Successful litigants opposing the government have often sought to have the government pay their fees in proceedings before the bankruptcy courts. Such cases arise when the government, acting as a creditor for example, unreasonably receives preferential payments on the eve of bankruptcy and then refuses to disgorge the money. ${ }^{4}$ Where the bankruptcy trustee, acting as representative of the estate, is forced to litigate the case, fee shifting against the government makes sense. If, say, the government unreasonably tries to force a debtor to undergo a Chapter 7 rather than a Chapter 11 bankruptcy proceeding, the govern-

$\dagger$ B.A. 1990, Indiana University; J.D. 1994, The University of Chicago.

1 "Fee shifting" simply means making a litigant pay attorneys' fees incurred by an opposing party in litigation.

2 See President's Council on Competitiveness, Agenda for Civil Justice Reform in America 24-26 (1991) (recommending a "loser pays rule for diversity cases and encouraging a moratorium on 'one-way' fee-shifting statutes that fail to compensate parties who must defend against non-meritorious claims"); David Margolick, Address by Quayle on Justice Proposals Irks Bar Association, NY Times A1 (Aug 14, 1991). For a detailed discussion of fee shifting from the Bush Administration's perspective, see Stuart M. Gerson, Fee-Shifting in Litigation, in National Legal Center for the Public Interest, A Plan to Improve America's Civil Justice System From the President's Council on Competitiveness 99-118 (1992).

3 Pub L No 96-481, 94 Stat 2325 (1980), codified as amended at 5 USC § 504, 28 USC \& 2412 (1988 \& Supp 1992). A private litigant will not be reimbursed where the government's position was "substantially justified." 28 USC \& 2412(d)(1)(A).

4 See, for example, In re Davis, 899 F2d 1136 (11th Cir 1990). 
ment's vast resources often skew the individual debtor's ability to pursue litigation. ${ }^{5}$ Moreover, creditors of a bankrupt are often other individuals or small businesses. The unreasonable use of government power to disadvantage these creditors is precisely the sort of abuse the EAJA is designed to alleviate. If debtors and competing creditors without the resources to litigate are unable to look to the EAJA they may be forced to knuckle under to the government, even if their positions are clearly correct. Still, while the power of most other courts to shift fees under the EAJA is explicitly established in the Act, ${ }^{6}$ or has been granted by judicial interpretations of the Act, ${ }^{7}$ whether bankruptcy courts can shift fees under the EAJA remains an open question.

A definite answer would satisfy the demands of those clamoring for a clear rule. Bankruptcy judges would no longer have to spend time and resources deciding if they have fee-shifting authority. Lawyers and their clients would know up front if there was any chance of fee recovery, allowing them to make informed choices about when to litigate and what resources to devote to their case.

Section I of this Comment examines the EAJA's historical background and analyzes its provisions, paying special attention to the principles of EAJA interpretation announced by the Supreme Court in Ardestani $v$ INS. ${ }^{8}$ Section II outlines the structure of bankruptcy courts and their place in the federal judicial system, then analyzes cases that have specifically addressed the authority of bankruptcy courts to shift fees under the EAJA. Section III discusses how other Article I courts (such as the Claims and Tax Courts) have resolved the question of their EAJA jurisdiction. Section IV concludes that the best resolution of the question is that the EAJA grants bankruptcy courts the power to shift fees against the government.

5 See, for example, O'Connor $v$ United States Department of Energy, 942 F2d 771, 774 (10th Cir 1991).

- For example, the EAJA explicitly mentions the United States Court of Veterans Appeals. See 28 USC \& 2412(d)(2)(F).

7 For example, in a case arising before the statute was amended to explicitly include the United States Claims Court (now the United States Court of Federal Claims), the Federal Circuit held that the Claims Court had power to shift fees under the EAJA. Essex Electro Engineers $v$ United States, 757 F2d 247 (Fed Cir 1985).

s 112 S Ct 515 (1991). 


\section{The Equal ACcess to JUSTICE ACT}

\section{A. Historical Background}

Participants in the American civil justice system have traditionally had to pay their own attorneys' fees, whether or not they initiated the proceeding and regardless of the judgment rendered. ${ }^{9}$ As a result, successful plaintiffs take home less money than their awarded damages, and even successful defendants end up worse off than they began.

To ameliorate the sometimes harsh results of this rule, nineteenth-century judges created narrow exceptions to the "American Rule." For instance, if a plaintiff's successful litigation created, preserved, or increased a "common fund" for the use of others, his legal expenses were paid from the fund. ${ }^{10}$ Another exception allowed fee shifting against a party whose conduct was malicious or vexatious. ${ }^{11}$ Common law exceptions, however, have narrow applicability and are geared toward redressing specific injustices after litigation. They are not designed to influence a party's initial decision to litigate.

Moving beyond these judicially created exceptions, Congress has created statutory exceptions to the American Rule. These statutory provisions generally allow fee shifting as an adjunct to the larger purposes of a statute, and differ from common law exceptions with regard to the circumstances under which a party

9 This is the "American Rule," in contrast to the British system of "loser pays," called the "English Rule." For detailed treatments of the American Rule's development, see John Leubsdorf, Toward a History of the American Rule on Attorney Fee Recovery, 47 L \& Contemp Probs 9 (1984); Alyeska Pipeline Service Co. $v$ Wilderness Society, 421 US 240, 247-62 (1975).

10 See Trustees $v$ Greenough, 105 US 527, 532-33 (1882). This exemption reflects the theory that it would be unfair for one individual to bear the cost of a successful legal action that benefited an entire ascertainable class. Id at 532. More recently, the Supreme Court has recognized a broader variant of the "common fund" exception, the "substantial benefit" exception. Here, an individual plaintiff must confer some benefit on a specific class, and the court must have some power over a defendant that enables it to make a fee award to the plaintiff from the losing defendant. See Hall $v$ Cole, 412 US 1, 5 (1973). Even though the plaintiff has not created a fund, as in the "common fund" exception, his fees are paid, because otherwise the plaintiff would bear all the costs even though many members of the plaintiff class have benefited. A prominent example is the shareholder derivative suit, where the losing corporation pays the fees of an individual litigant shareholder, thus spreading among all shareholders the expenses of vindicating the corporate right of action. See Mills $v$ Electric Auto-Lite, 396 US 375, 394 (1970). For details on the development and practice of the common fund exceptions, see John P. Dawson, Lawyers and Involuntary Clients: Attorney Fees From Funds, 87 Harv L Rev 1597 (1974); Herbert B. Newberg, Attorney Fee Awards § 2.01 (McGraw-Hill, 1986 \& Supp 1992).

12 See F.D. Rich Co. v Industrial Lumber Co., 417 US 116, 129-30 (1974); Hall, 412 US at 5. 
may receive attorneys' fees. ${ }^{12}$ For example, the Clayton Act provides for a mandatory award of attorneys' fees to successful antitrust plaintiffs, ${ }^{13}$ while the Administrative Procedure Act authorizes courts to award attorneys' fees to prevailing plaintiffs in Freedom of Information Act actions against federal agencies. ${ }^{14}$ The statutory framework created by these laws is disorganized and arbitrary, seemingly dictated more by the strength of a given lobby than by a desire to bring harmony to the civil justice system. A similar patchwork of laws has developed in the states. ${ }^{15}$

In addition to these common law and statutory exceptions, contractual arrangements provide a third means of circumventing the American Rule. ${ }^{16}$ It is not uncommon for parties to agree during contract negotiations on how attorneys' fees will be divided in the event that the contract breaks down and gives way to litigation. However, the government has often been reluctant to enter into contracts that could shift fees against it. ${ }^{17}$

Significantly, modern law has increasingly used fee shifting to encourage litigation viewed as beneficial to society. This use of fee shifting to advance broader notions of social justice departs from the common law tradition, in which narrow fee-shifting exceptions were tailored to mitigate specific injustices or to punish specific abuses. One important objective of these changes to the American Rule has been to make possible the private enforcement of public policy. Fee shifting helps the citizen to play the role of a "private attorney general," and several statutes specifically cite private enforcement as a rationale for fee shifting. ${ }^{18}$ In

12 See generally Robert H. Aronson, Attorney-Client Fee Arrangements: Regulation and Review 127-41 (Federal Judicial Center, 1980); Frances Kahn Zemans, Fee Shifting and the Implementation of Public Policy, 47 L \& Contemp Probs 187, 195-200 (1984); Newberg, Attorney Fee Awards ch 8-9, 20 (cited in note 10).

${ }^{13}$ See 15 USC \& 15 (1988).

14 See 5 USC $\S 552(a)(4)(E)$ (1988). See also Securities Exchange Act of 1934,15 USC $\S \S 78 \mathrm{i}(\mathrm{e}), 78 \mathrm{r}(\mathrm{a})$ (1988) (allowing the court to award fees to either plaintiffs or defendants in its discretion).

${ }_{15}$ See Comment, Institutionalizing An Experiment: The Extension of the Equal Access to Justice Act-Questions Resolved, Questions Remaining, 14 Fla St U L Rev 925, 926 (1987); Note, State Attorney Fee Shifting Statutes: Are We Quietly Repealing the American Rule?, 47 L \& Contemp Probs 321 (1984).

${ }^{16}$ See Fleischmann Distilling Corp. v Maier Brewing Co., 386 US 714, 717 (1967).

17 There have been some signs of increasing government acceptance of contractual fee shifting. In its waning days, the Bush Administration issued a wide-ranging executive order that included an instruction that federal attorneys should try to engage in fee shifting whenever possible within the existing statutory framework. See Executive Order 12778, 3 CFR 359 (1991).

${ }^{18}$ See Newman $v$ Piggie Park Enterprises, 390 US 400, 401-02 (1968). Statutes 
the 1960s and 1970s, some courts, in order to encourage such private enforcement, permitted fee shifting where a litigant was enforcing perceived public policy, even in the absence of statutory fee-shifting authority. ${ }^{19}$

In 1975, however, the Supreme Court rejected this judicial expansion of fee shifting, decisively reiterating the hard-edged American Rule and striking down the use of the judicially created private attorney general exception. In Alyeska Pipeline Service Co. $v$ Wilderness Society, the Court voted 5-2 to forbid judges from engaging in fee shifting in the absence of specific statutory or common law authorization. ${ }^{20}$ Congress, the Court reasoned, had always reserved the power to modify the long-standing American Rule, and thus it was beyond the equity powers of judges to make unilateral changes to the rule. ${ }^{21}$ "[I]t is not for us to invade the legislature's province by redistributing litigation costs ...."22

In order to preserve the private enforcement of public policy after Alyeska, Congress expanded statutory fee-shifting authority. ${ }^{23}$ Congress began to pass specific statutes encouraging fee shifting for the public benefit. This process began with the Civil Rights Attorneys' Fees Awards Act of 1976, which allowed fee shifting in certain civil rights actions. ${ }^{24}$ Congress continued on this path, passing a series of laws that provided for fee shifting in the pursuit of the social good. ${ }^{25}$

allowing fees for successful "citizen suits" to bring about enforcement include the Civil Rights Act of 1964, 42 USC § 2000a-3(b) (1988); the Civil Rights Attorneys' Fees Awards Act, 42 USC § 1988 (1988); the Clean Air Act, 42 USC § 7604(d) (1988); and the Safe Drinking Water Act, 42 USC § 300j-8(d) (1988).

19 See, for example, Brandenburger $v$ Thompson, 494 F2d 885, 888-89 (9th Cir 1974) (awarding a plaintiff fees for "vindicating the federally protected right of interstate travel free from the forfeiture of welfare benefits"); Knight $v$ Auciello, 453 F2d 852, 853 (1st Cir 1972) (holding a plaintiff was entitled to fees in a suit to enforce equal housing rights under 42 USC § 1982); Lee $v$ Southern Home Sites Corp., 444 F2d 143, 147 (5th Cir 1971) (same). See generally Wilderness Society v Morton, 495 F2d 1026, 1029-30 (DC Cir 1974) (listing cases applying the private-attorney general exception), rev'd as Alyeska Pipeline Service Co. $v$ Wilderness Society, 421 US 240 (1975).

\footnotetext{
20421 US 240 (1975).

21 Id at 260-64.

22 Id at 271.
}

${ }^{23}$ See Comment, 14 Fla St U L Rev at 928-30 (cited in note 15); Robert V. Percival and Geoffrey P. Miller, The Role of Attorney Fee Shifting in Public Interest Litigation, $47 \mathrm{~L}$ \& Contemp Probs 233, 233 n 2 (1984).

24 Pub L No 94-559, 90 Stat 2641 (1976), codified at 42 USC $\S 1988$ (1988).

${ }_{25}$ See, for example, Civil Service Reform Act of 1978, 5 USC § 5596(b)(1) (1988); Age Discrimination Act, 42 USC \& 6104(e)(1) (1988). 


\section{B. The EAJA's Provisions}

In 1980 , this pattern of Congressional action culminated in the passage of the Equal Access to Justice Act. ${ }^{26}$ Congress designed the EAJA to vastly expand the statutory exceptions to the American Rule. The EAJA provided for fee shifting against the United States in favor of successful private litigants in a wide variety of contexts, whether the private party was the plaintiff or defendant. The EAJA's stated purpose was to level the playing field for private citizens and businesses, especially those of lesser means, in litigation with the government. ${ }^{27}$ Specifically, Congress created the EAJA to remove "economic deterrents to contesting governmental action" and to discourage government agencies from coercing compliance with regulations that might otherwise not be adequately contested. ${ }^{28}$

As a first step, the EAJA made the government subject to fee shifting to the same extent as any private litigant. Prior to the adoption of the EAJA, sovereign immunity had exempted the federal government from the common law fee-shifting provisions applicable to private parties. ${ }^{29}$ In those instances where Congress had expressly waived immunity by statute, the federal government was exposed to fee shifting, but not otherwise. ${ }^{30}$ The EAJA extinguished this immunity. ${ }^{31}$ If the conduct of government lawyers is malicious or vexatious, a judge can tax the government with the attorneys' fees of the other party-just as the common law provides for private litigants. Moreover, the government is now liable for attorneys' fees under statutes that do not expressly waive sovereign immunity, if the statutes make private parties liable.

The EAJA did more than merely place the government on the same plane as private litigants. Expanding fee shifting far beyond its previous boundaries, the EAJA mandated fee shifting in favor of a prevailing party in any non-tort civil action by or

${ }^{26}$ Pub L No 96-481, 94 Stat 2325 (1980), codified as amended at 5 USC $\S 504,28$ USC \& 2412 (1988 \& Supp 1992).

${ }_{27}$ See EAJA § 202,94 Stat at 2325; Sullivan v Hudson, 490 US 877, 883 (1989).

2s EAJA, HR Rep No 96-1418, 96th Cong, 2d Sess 5-6, 9-10 (1980), reprinted in 1980 USCCAN 4984, 4988.

${ }^{29}$ See Alyeska, 421 US at 267-68 \& n 42; Ruckelshaus $v$ Sierra Club, 463 US 680, 685 (1983).

${ }^{30}$ Sierra Club, 463 US at 685.

31 "The United States shall be liable for [ ] fees and expenses to the same extent that any other party would be liable under the common law or under the terms of any statute which specifically provides for such an award." 28 USC § 2412(b). 
against the United States, absent substantial government justification or special circumstances. Specifically, the EAJA ordered that:

a court shall award to a prevailing party other than the United States fees and other expenses . . . incurred by that party in any civil action . . . brought by or against the United States in any court having jurisdiction of that action, unless the court finds that the position of the United States was substantially justified or that special circumstances make an award unjust. ${ }^{32}$

As discussed below, the dispute among the courts over the ability of bankruptcy courts to shift fees under the EAJA arises from disagreements over the scope of the terms "a court" and "any court having jurisdiction of that action." ${ }^{\prime 3}$

The EAJA also contains a provision which mandates fee shifting in administrative adjudications involving the government. This provision, codified at 5 USC $\S 504$, extends the practical impact of the EAJA far beyond court proceedings, so in total the EAJA allows fee recovery from the government in the vast majority of proceedings where the federal government is adverse to private litigants.

Section 504 provides that "[a]n agency that conducts an adversary adjudication shall award" attorneys' fees to a prevailing party other than the United States. ${ }^{34}$ The "adjudicative officer of the agency" makes the determination of whether the government's position was substantially justified or whether other extenuating circumstances exist that militate against fee shifting. ${ }^{35}$ Of course, because bankruptcy courts are not administrative agencies, the question of the fee-shifting power of the bankruptcy courts is directly related only to the EAJA provision in Title 28. However, courts often look to Title 5's $\S 504$ as well as Title 28's $\S 2412$ when questions of EAJA interpretation arise. ${ }^{36}$

The Supreme Court recently clarified principles of EAJA interpretation in Ardestani $v$ INS.$^{37}$ Ardestani involved an Iranian immigrant fleeing persecution in her home country whom the

3228 USC $\S 2412(d)(1)(A)$.

33 Courts commonly refer to the authority to award fees under the EAJA as "EAJA jurisdiction." This Comment follows this convenient, if imprecise, practice.

${ }^{34} 5$ USC \& 504(a)(1).

35 Id.

${ }^{36}$ See, for example, Hudson, 490 US at $890-93$.

37112 S Ct 515 (1991). 
Immigration and Naturalization Service strove vigorously and unjustifiably to deport. ${ }^{38}$ After prevailing in an administrative deportation proceeding, Ardestani filed for an award of fees under the EAJA. The question before the Court was whether administrative deportation hearings are within the scope of the EAJA. $^{39}$

In denying Ardestani's claim, the Supreme Court relied heavily on the plain language of the EAJA. The Court noted that examining the language should be the threshold inquiry of any statutory analysis. ${ }^{40}$ The "most natural reading of the EAJA" led to the conclusion that deportation proceedings were not within its scope. ${ }^{41}$ The EAJA's legislative history was sparse and ambiguous, certainly not adequate to override the "strong presumption' that the plain language of the statute expresses congressional intent."

In addition, the Court reasoned that the EAJA was only a partial waiver of sovereign immunity, and as such had to be strictly construed in the government's favor. ${ }^{43}$ The Court did not say that courts should automatically narrow waivers of sovereign immunity whenever there is ambiguity; rather, if the plain language excluded an interpretation that would allow fee shifting, that exclusion was "reinforced" by the principle that waivers of sovereign immunity will not be implied freely. ${ }^{44}$ The Court expressed unhappiness with the result it reached, as it clearly went against the congressional objectives behind the EAJA. ${ }^{45}$ But the

${ }^{38}$ The INS tried to deport Ardestani on the grounds that she had reached a "safe haven" from persecution by establishing residency in Luxembourg prior to coming to the United States. In fact, Ardestani had apparently stayed in a hotel in Luxembourg for 3 days and had not established residency. Id at 517.

39 Id.

40 Id at 519. The statutory question in Ardestani was whether the phrase "adjudication under section 554 [of the Administrative Procedure Act]," 5 USC $\S 504(b)(1)(C)(i)$ (1988), implied a limitation to adjudications defined in section 554. See $112 \mathrm{~S} \mathrm{Ct}$ at 518.

$41112 \mathrm{~S}$ Ct at 519.

42 Id at 520.

43 Id.

44 Id.

${ }^{45}$ Id at 521. Justice Blackmun's dissent stressed the harshness of the Court's position, noting that aliens with inadequate money to defend against unreasonable government action could be shipped back to face death in their homelands. Id at 522. Blackmun felt that Ardestani contradicted the Court's previous statement that the EAJA must be interpreted in light of its undenied purpose "to diminish the deterrent effect of seeking review of, or defending against, governmental action." Id at 524, quoting Hudson, 490 US at 890 . 
Court noted that Congress had twice amended the EAJA in response to jurisdictional questions, and could easily do so again. ${ }^{46}$

\section{BANKRUPTCY COURTS AND THE EAJA}

When private litigants invoke the EAJA in an effort to recover attorneys' fees from the government in bankruptcy proceedings, bankruptcy courts must face the question of whether they have the power to shift fees under the EAJA. The policies behind the EAJA become particularly relevant where the government, for example, attempts to use its superior power to the disadvantage of less powerful creditors, whether individuals or small businesses.

A. The Structure of Bankruptcy Courts and Their Place in the Federal System

Each federal circuit court of appeals appoints the bankruptcy judges attached to its federal judicial districts, in numbers established by statute for each district. ${ }^{47}$ Each bankruptcy court is an adjunct of a particular district court; for each district court there is one bankruptcy court. ${ }^{48}$ Bankruptcy judges serve fourteenyear terms. ${ }^{49}$ While bankruptcy courts are competent to adjudicate most cases and proceedings relating to bankruptcy, the district court may summarily withdraw a case or proceeding from a bankruptcy court $^{50}$ and has jurisdiction over bankruptcy appeals. ${ }^{51}$

Much of the dispute over the power of bankruptcy courts to shift fees under the EAJA stems from the fact that bankruptcy courts are considered Article I courts. This warrants a brief review of the distinction between Article I courts and Article III courts. These courts are so named for the articles of the Constitution which give Congress the authority to establish them. Article III courts are the Supreme Court and those "inferior Courts as the Congress may from time to time ordain and establish"-primarily the federal courts of appeals and district courts. $^{52}$ Judges who sit on Article III courts hold their office

$46 \quad 112 \mathrm{~S} \mathrm{Ct}$ at 521.

47 See 28 USC \$ 152(a)(1) (1988).

48 See 28 USC \& 151 (1988).

49 See 28 USC \& 152(a)(1).

50 28 USC \& 157(d) (1988).

5128 USC \& 158 (1988).

62 US Const, Art III, $\S 1$. There are and have been other Article III courts. The Court 
during good behavior, and their pay cannot be reduced while they are in office. ${ }^{53}$ Article I courts, by contrast, are those established by Congress under its power "[t]o constitute Tribunals inferior to the supreme Court." ${ }^{\text {"54 }}$ There is no constitutional requirement that the judges in these courts have life tenure or that their pay not be reduced while in office. Examples of Article I courts include the bankruptcy courts, ${ }^{55}$ the Tax Court, ${ }^{56}$ and the Court of Veterans Appeals. ${ }^{57}$ Article III and Article I courts are defined by the prerogatives of their judges; bankruptcy courts are indisputably Article I courts, because their judges do not meet the Article III requirements of life tenure and guaranteed salary. ${ }^{58}$ Unquestionably, the EAJA empowers Article III courts to shift fees. Less certain, however, is whether the statute confers such authority on Article I courts. ${ }^{59}$.

\section{B. Circuit Court Decisions About the EAJA Jurisdiction of Bankruptcy Courts}

The Tenth and Eleventh Circuits have disagreed about the fee-shifting power of bankruptcy courts. The Eleventh Circuit maintains that bankruptcy courts do not have authority to shift fees under the EAJA, while the Tenth asserts that they do. A number of other courts have simply assumed, without extensive discussion, that EAJA jurisdiction inheres in bankruptcy courts.

of International Trade is an Article III court, adjudicating civil actions against the United States arising from federal laws governing import transactions. See 28 USC \& 251 (1988). The Court of Claims was an Article III court until 1982, when it was reorganized as the Article I Claims Court (now called the Court of Federal Claims). See 28 USC \& 171(a) (1988 \& Supp 1992); Office of the Federal Register, United States Government Manual 93/94 77-78 (US GPO, 1993).

s3 US Const, Art III, $\$ 1$.

54 US Const, Art I, § 8 .

${ }^{55}$ See Northern Pipeline Construction Co. v Marathon Pipe Line Co., 458 US 50, 6061 (1982).

${ }^{56}$ See 26 USC $\$ 7441$ (1988).

${ }^{37}$ See 38 USC $\$ 4051$ (1988).

${ }^{38}$ Northern Pipeline, 458 US at 60-61.

59 The Court has also noted a distinction between the two types of courts based on the types of cases they decide. Article I courts may not adjudicate "private rights," which are essentially rights guaranteed by the Constitution. They may, however, adjudicate "public rights," or rights created by federal statute. See id at 50. 
1. Davis: No EAJA jurisdiction for bankruptcy courts.

The Eleventh Circuit held in In re Davis that bankruptcy courts have no EAJA jurisdiction. ${ }^{60}$ Davis, a farmer, accepted a loan from the Farmers Home Administration (FHA), a governmental agency. He very soon went bankrupt. The bankruptcy trustee sued the FHA to recover payments that Davis had made before his bankruptcy, and to subordinate the claims of the government to those of other creditors. ${ }^{61}$ After a decision in favor of the trustee, he filed to recover attorneys' fees from the FHA under the EAJA. The bankruptcy court granted the trustee's request, and the district court upheld the fee award. ${ }^{62}$ The Eleventh Circuit reversed, holding that bankruptcy courts lacked EAJA jurisdiction. ${ }^{63}$

The Davis court relied on an earlier Eleventh Circuit decision, Bowen $v$ Commissioner, which held that the Tax Court, another Article I Court, did not have EAJA jurisdiction. ${ }^{64}$ Davis reasoned that the jurisdictional questions in the two cases were identical, and thus that Bowen dictated the outcome in Davis. ${ }^{65}$

Bowen is a short per curiam opinion, which engages in only the most cursory statutory analysis and inartfully juggles certain sections of Title 28 that contain the phrase "court of the United States." Bowen begins with 28 USC $\S 451$, the definitional section of Title 28. ${ }^{66}$ Section 451-explicitly limited to Title $28^{67}$-defines "court of the United States" as including the Supreme Court, the courts of appeals, the district courts, and any court created by Congress whose judges hold office during good behavior. ${ }^{68}$ This definition therefore excludes Article I courts, because their judges hold office for fixed terms.

The Bowen court then applied this definition of "court of the United States" to $\S 2412$, the EAJA. The court observed that under $\S$ 2412(a), a court may award, to a prevailing party, those costs enumerated under 28 USC $\S 1920 ;{ }^{69} \S 1920$ permits the

60 899 F2d 1136, 1145 (11th Cir 1990).

${ }^{61}$ See id at 1137; 11 USC $\S \S 510(c), 547(b), 547(c)(5)(1988)$.

62899 F2d at 1138.

Id at 1142.

706 F2d 1087, 1088 (11th Cir 1983) (per curiam).

${ }_{65}$ Davis, $899 \mathrm{~F} 2 \mathrm{~d}$ at $1139 \mathrm{n} 7$.

66 Bowen, $706 \mathrm{~F} 2 \mathrm{~d}$ at 1088.

67 "As used in this title . . . 'court of the United States' includes . . . ." 28 USC § 451 (1988) (emphasis added).

68 Id.

69 706 F2d at 1088. 
taxing of certain court costs by "any court of the United States." The Bowen court concluded that the meaning of "court of the United States" under $\S 1920$ was controlled by the $\S 451$ definition and therefore included only Article III courts. ${ }^{71}$ The Bowen court then reasoned that an award of $\S 1920$ costs to a prevailing party under $\S 2412$ (a) of the EAJA is limited to Article III courts. ${ }^{72}$

Moving on to the precise question of attorneys' fees, the court noted that subsections 2412(b) and (d) allow an award of fees and expenses "in addition to those awarded pursuant to [2412(a)]."73 The Bowen court reasoned that it would be "anomalous" to allow an Article I court to award attorneys' fees and other expenses under 2412(b) and (d) when Article I courts could not, according to this analysis, award court costs under $\S 2412(a)$. To avoid this anomaly, the Bowen court concluded that an Article I Court had no authority to award expenses, costs, or fees under $\S 2412 .^{74}$

Bowen bolstered its holding with reference to rather hazy legislative history, primarily the statement of Senator Gaylord Nelson, co-sponsor of the EAJA, that the EAJA would not be available in cases before the Tax Court. ${ }^{75}$ Furthermore, Bowen noted that Congress later created a separate EAJA-type fee-shifting provision in the Internal Revenue Code in $1982 .{ }^{76}$ The court looked to the legislative history of these amendments and concluded they were intended to respond to $\S 2412$ 's failure to extend EAJA jurisdiction to Article I courts. ${ }^{77}$

Davis accepted Bowen's reasoning, stating that it "unambiguously control[led]" the question of EAJA jurisdiction for all Article I courts, including bankruptcy courts. ${ }^{78}$ The court added some discussion of legislative history and distinguished the ap-

7028 USC \& 1920 (1988). These costs include, for example, fees for the clerk, marshal, and court reporter, and printing, copying, and docketing fees. Id.

71706 F2d at 1088.

${ }^{72}$ Id. The court implicitly assumed that "court of the United States" under $\S \S 451$ and 1920 refers to the same entities as "court" under $\S 2412$.

${ }_{73}$ As discussed earlier, 28 USC $\$ 2412(\mathrm{~b})$ makes the United States liable for attorneys' fees under the common law exceptions to the American Rule; § 2412(d) orders fee shifting unless the government's position was "substantially justified."

706 F2d at 1088.

75 Id.

76 Id. See 26 USC $\$ 7430$ (1988).

${ }_{77}$ See Miscellaneous Revenue Act of 1981, HR Rep No 97-404, 97th Cong, 1st Sess 10 (observing that the EAJA is not available to cases in the Tax Court because it is not an Article III court). See text accompanying notes 118-32 for a fuller discussion of this section of the Internal Revenue Code and its importance.

${ }^{78}$ Davis, 899 F2d at 1139. 
parently contrary authority of Essex Electro Engineers $v$ United States, ${ }^{79}$ a Federal Circuit case decided after Bowen.

Davis went further than Bowen, explicitly equating the term "court" in $\S 2412$ with the phrase "court of the United States" contained in $\S 451$ 's definition. Though the EAJA itself refers only to a "court," the House Report accompanying the bill stated that the courts referred to in 28 USC $\S 2412(\mathrm{~b})$ were those defined in 28 USC $\S 451$ as "courts of the United States." ${ }^{80}$ Although the Report made no such statement regarding $\$ 2412(\mathrm{~d})$, Davis noted that the relevant language of $2412(\mathrm{~b})$ and (d) was identical, and thus extrapolated the Report's statement to cover $\S$ 2412(d). ${ }^{81}$ This meant that an Article I court could not shift any fees, because, somewhat counter-intuitively, it was not a "court of the United States."

The Davis court also inferred congressional intent from the fact that Congress amended the EAJA to include the Article I Claims Court. In response to questions raised about the Claims Court's ability to shift fees under the EAJA, in 1985 Congress made explicit that the word "court" in $\$ 2412$ (a) included the Claims Court. ${ }^{82}$ Davis said that Congress's failure to make a similar amendment to include the Tax Court or bankruptcy courts indicated that Congress did not want those courts to have EAJA jurisdiction. ${ }^{83}$

In a lengthy footnote, Davis attempted to distinguish Essex Electro, ${ }^{84}$ in which the Federal Circuit rejected Bowen and held that the Article I Claims Court had EAJA jurisdiction (prior to the 1985 amendment providing such jurisdiction). To that end, Davis pointed to special circumstances surrounding Essex Electro. When Congress transmuted the Court of Claims, which had been an Article III court, into the Claims Court, it provided that EAJA applications pending before the Court of Claims at the time of switchover would be decided by the new Article I Claims Court. ${ }^{85}$ From this limited initial EAJA jurisdiction, the Essex

79757 F2d 247 (Fed Cir 1985). See text accompanying notes 84-87.

so HR Rep No 96-1418 at 17, reprinted in 1980 USCCAN 4984, 4996 (cited in note 28).

$81899 \mathrm{~F} 2 \mathrm{~d}$ at 1139.

82 Id at $1139 \mathrm{n} 7$. See Act of $1985 \S 2$ (c)(2)(F), Pub L 99-80, 99 Stat 183, 185, codified at 28 USC § 2412(d)(2)(F) (1988); Equal Access to Justice Act Amendments, HR Rep No 99-120, 99th Cong, 1st Sess 17-18 (1985).

$83899 \mathrm{~F} 2 \mathrm{~d}$ at $1139 \mathrm{n} 7$.

84 757 F2d 247.

85 Davis, 899 F2d at 1139 n 7. See Federal Courts Improvement Act of 1982 (FCIA) § 403(d), Pub L No 97-164, 96 Stat 25, 58. In 1982, Congress created the Article I Claims 
Electro court inferred that Congress intended the Claims Court to have subsequent EAJA jurisdiction as well..$^{86}$ Davis noted that this line of reasoning did not apply to bankruptcy courts or to the Tax Court, because no similar change in the court structure had occurred. Accordingly, Davis concluded that Essex Electro derived from the unique situation of the Claims Court and thus did not apply to bankruptcy courts. ${ }^{87}$

Davis's reliance on Congress's amending the EAJA to explicitly include the Claims Court (while not including the Tax or bankruptcy courts) is misplaced for two reasons. First, Congress did not say that it was adding the Claims Court to the authorized courts; rather, it clarified that the definition of "court" included the Claims Court, thus "codif[ying] existing law." Davis even quoted this language, but without drawing the inference that Congress thought the Claims Court, and by implication other Article I courts, had always been included under the EAJA. ${ }^{89}$

Second, the Claims Court jurisdictional issue was an actively disputed matter in 1985, having arisen several times in the courts. In contrast, there was no judicial dispute about EAJA jurisdiction for bankruptcy courts (though a few courts had assumed such jurisdiction). ${ }^{90}$ Furthermore, Davis ignored the reason there was no congressional dispute about the Tax Court in 1985: Congress had enacted an EAJA-type provision in the Tax Code three years earlier, explicitly withdrawing tax matters from the scope of the EAJA. ${ }^{91}$ Thus, it follows that Congress did not amend the EAJA in 1985 to allow the Tax Court or the bankruptcy courts to shift fees because the fee-shifting power of the

Court as the successor to the Article III Court of Claims. FCIA $\S \S 105,133,139,96$ Stat at $26-28,39-41,42-44$.

${ }^{86}$ See Essex Electro, 757 F2d at 252.

$87899 \mathrm{~F} 2 d$ at $1139 \mathrm{n} 7$.

88 HR Rep No 99-120 at 17-18 (cited in note 82).

$8989 \mathrm{~F} 2 \mathrm{~d}$ at $1139 \mathrm{n} 7$.

so No court explicitly addressed the question before the Davis court in 1990. For example, Matter of Esmond involved a bankruptcy court's rejection of a debtor's application for fees under the EAJA. 752 F2d 1106 (5th Cir 1985). The Fifth Circuit remanded the case to the bankruptcy court for consideration of whether the government had been substantially justified in its position, a threshold requirement for awarding fees under the EAJA. Id at 1109. The Fifth Circuit thus implicitly assumed the jurisdiction of the bankruptcy court to award fees, although it did not actually address the question of feeshifting authority. See also In re Hagan, 44 Bankr 59 (Bankr D RI 1984); In re Armstead, 106 Bankr 405 (Bankr E D Penn 1989).

${ }_{91}$ Tax Equity and Fiscal Responsibility Act of $1982 \S 292(a)$, Pub L No 97-248, 96 Stat 324, 572-73, codified at 26 USC § 7430 (1988). 
Tax Court was no longer an issue after 1982, and because the authority of the bankruptcy courts had not been questioned until Davis itself.

At some level, the Davis court seemed apologetic for its decision. It admitted the incongruity of denying EAJA jurisdiction to bankruptcy courts, given EAJA's seemingly broad scope. Ultimately, Davis simply noted that "[t]his Court remains bound by the panel decision in Bowen [] until and unless it is modified by the Supreme Court or by this Court sitting en banc. ${ }^{192}$

The Eleventh Circuit returned to the fee-shifting authority of bankruptcy courts in In re Brickell Investment Corp. ${ }^{93}$ Brickell relied on Davis and Bowen in holding that a bankruptcy court lacked jurisdiction to award fees against the government under 26 USC $\S 7430$, the fee-shifting provision of the Tax Code. ${ }^{94}$ Section 7430 provides that in any "administrative or court proceeding" regarding tax matters, ${ }^{95}$ the prevailing party may recover fees where the government's position was not "substantially justified." "Court proceeding" is defined as "any civil action brought in a court of the United States (including the Tax Court and the United States Claims Court)." ${ }^{\prime 97}$

Brickell decided that Davis and Bowen controlled its decision. Because $\$ 7430$ limited its scope to actions brought in a "court of the United States" and bankruptcy courts were not "courts of the United States" under the definitional section of Title 28, bankruptcy courts lacked jurisdiction to shift fees under 26 USC \& 7430 as well as 28 USC $\S 2412$. Davis and Bowen, which had concerned the interpretation of the EAJA, were applicable because interpretations of $\S 7430$ had often relied on precedent interpreting the EAJA, given the common roots of the two feeshifting provisions. ${ }^{98}$

$92899 \mathrm{~F} 2 \mathrm{~d}$ at $1140-41 \mathrm{n} 7$.

93922 F2d 696 (11th Cir 1991).

r In 1982, Congress had amended the EAJA to provide that henceforth all questions of fee shifting that fell under $\S 7430$ would no longer be governed by the EAJA. Tax Equity and Fiscal Responsibility Act $\$ 292$ (c), 96 Stat at 574 (cited in note 91) (adding subsection (e) to 28 USC \& 2412).

${ }^{95} 26$ USC $\$ 7430$ (a) (1988).

96 26 USC $\S 7430(\mathrm{c})(4)(\mathrm{A})$. Under $\$ 7430$, the taxpayer bears the burden of proof regarding the lack of substantial justification, unlike under the EAJA, where the judge decides whether the government was substantially justified. However, this makes no difference for the question of which courts have jurisdiction to award fees.

${ }^{97} 26$ USC $\$ 7430(c)(6)$.

${ }_{98}$ Brickell, 922 F2d at 700-01. See, for example, Huffman $v$ Commissioner, 978 F2d 1139,1143 (9th Cir 1992) ("The reasoning employed by the courts under the attorney's fees provision of the [EAJA] applies equally to review under section 7430."). 
Brickell, too, has important flaws in its logic. First, the definition in Title 28 of the phrase "court of the United States" is explicitly limited to that title. ${ }^{99}$ Section 7430 , of course, is in Title 26-the Title 28 definition should not necessarily control. Moreover, the wording of $\S 7430$ implies that "court of the United States" already includes the Tax Court and the Claims Court, although they clearly do not fall within the Title 28 definition (because they are Article I courts). If Congress had indeed meant to use "court of the United States" in $\S 7430$ in the same sense as in Title 28, and then to add the Tax and Claims Courts to those courts having fee-shifting authority, it is unlikely Congress would have used the phrase "including the Tax Court and the United States Claims Court."100 "Including" implies that those courts are already encompassed by "court of the United States." A phrase such as "in addition to" or "plus," rather than "including," would have been more consistent with a congressional view that the Tax and Claims Courts were not "courts of the United States." The Eleventh Circuit has thus twice held that bankruptcy courts lack fee-shifting authority under the EAJA or other fee-shifting statutes. Both decisions, however, rest on severely flawed reasoning.

\section{O'Connor: Bankruptcy courts have EAJA jurisdiction.}

The Tenth Circuit rejected Davis in O'Connor $v$ United States Department of Energy. ${ }^{101}$ The Department of Energy ("DOE"), one of O'Connor's creditors in bankruptcy, filed several adversarial motions in bankruptcy court. The court denied the government's motions, then awarded fees and costs to O'Connor under the EAJA. ${ }^{102}$ The DOE appealed to the district court, which relied on Davis in reversing the fee award. The Tenth Circuit in turn reversed the district court. ${ }^{103}$

The O'Connor court relied on plain language rather than legislative history. Citing Supreme Court authority, it held that its "judicial inquiry is complete" when the language of a statute is clear. ${ }^{104}$ "A court should venture into the thicket of legislative

99 See note 67.

10026 USC \& 7430(c)(6).

101942 F2d 771 (10th Cir 1991). See also Tom Carter Enterprises v Danning, 159 Bankr 557, 561 (Bankr C D Cal 1993) (adopting the O'Connor analysis to decide that it had authority to shift fees under the EAJA).

102942 F2d at 772.

103 Id.

${ }_{104}$ Id at 773, citing Rubin $v$ United States, 449 US 424, 430 (1981). 
history only when necessary to determine 'a statutory purpose obscured by ambiguity."'105 The court found complete clarity in the EAJA's phrases "court" and "any court having jurisdiction of that action." Using a standard dictionary, the O'Connor court reasoned that the "plain, ordinary and every day" meaning of "court" encompassed both Article I and Article III courts. ${ }^{106}$ Nor did Congress restrict the use of "court" to Article III courts, despite its ability to do so by simply using the well-known phrase "court of the United States." Therefore, the court held, judges should not read into the statute an intent to restrict its applicability. ${ }^{107}$

O'Connor explicitly rejected the Davis and Bowen analyses. First, § 1920's statement that a "court of the United States" may tax the enumerated costs does not constitute a restriction on which courts can tax costs under $\S 2412$ (a). Instead, § 2412(a) simply uses $\S 1920$ as a shorthand way of enumerating the costs that courts can tax to parties. ${ }^{108}$ O'Connor also rejected Davis's extrapolation of $\S 2412(\mathrm{~b})$ 's legislative history to $\S 2412(\mathrm{~d})$, finding it unpersuasive in the face of the clear meaning of the EAJA. After criticizing the Eleventh Circuit's analyses, O'Connor also noted that several courts had assumed the ability of bankruptcy courts to make EAJA fee awards. ${ }^{109}$

The O'Connor court noted that its conclusion was "congruous with the statutory scheme" and consistent with the EAJA's purpose "to encourage individuals and small businesses to challenge adverse government action notwithstanding the high cost of civil litigation." The establishment by Congress of an administrative version of the EAJA did not show any congressional desire to limit the scope of the EAJA to specific courts. Rather, it showed the opposite-that Congress wanted the EAJA to have as broad a scope as possible.

${ }^{105} 942$ F2d at 773, quoting Burlington Northern R.R. Co. v Oklahoma Tax Commission, 481 US 454, 461 (1987).

${ }_{106} 942$ F2d at 773, citing Webster's II New Riverside University Dictionary 320 (Riverside, 1984) (defining "court" as "a person or group of persons whose task is to hear and submit a decision on cases at law").

107 942 F2d at 773-74.

108 Id.

100 Id at 774, citing Matter of Esmond, 752 F2d 1106 (5th Cir 1985); In re Armstead, 106 Bankr 405 (Bankr E D Pa 1989); In re Hagan, 44 Bankr 59 (Bankr D RI 1984).

$110942 \mathrm{~F} 2 \mathrm{~d}$ at 774. 


\section{THE POWER OF OTHER ARTICLE I COURTS UNDER THE EAJA}

As shown above, the question of whether bankruptcy courts have EAJA jurisdiction is part of the larger question of whether Article I courts in general have EAJA jurisdiction. Examining judicial opinions considering the EAJA jurisdiction of other Article I courts casts light on the problem of bankruptcy court EAJA jurisdiction. Many courts have recognized the power of non-bankruptcy courts to shift fees under the EAJA. Congressional action has explicitly given some of these courts EAJA fee-shifting power.

\section{A. The Court of Federal Claims (The Claims Court)}

The Court of Federal Claims is an Article I court that has jurisdiction over many claims of money judgments against the United States. ${ }^{111}$ It was established in 1982, succeeding to the jurisdiction of the Article III Court of Claims. ${ }^{112}$ Its decisions are appealable to the Federal Circuit. ${ }^{113}$

In Essex Electro Engineers $v$ United States, the Federal Circuit held that the Claims Court had EAJA jurisdiction to award fees, even though it was an Article I court. ${ }^{114}$ The court relied primarily on the EAJA's plain language, buttressed by Congress's rolling over the jurisdiction of the Court of Claims to the Court of Federal Claims. ${ }^{115}$ Essex Electro found Bowen's reliance on 28 USC $\S 1920$ to be inappropriate, reasoning that $\S 1920$ was designed simply to enumerate which costs a court could award, not to limit which courts had authority to award fees. ${ }^{116}$

While Essex Electro partially dealt with circumstances unique to the Claims Court, it concluded that plain language overrode Bowen's somewhat tortured insertion of $\S 1920$ into $\S$ 2412. Thus, Essex Electro supports O'Connor in holding that EAJA fee shifting is not limited to Article III "courts of the Unit-

111 Until the fall of 1992, the Court of Federal Claims was known as the United States Claims Court. See Federal Courts Administration Act of 1992 \& 902, Pub L 102-572, 106 Stat 4506, 4516. Congress made no substantive change to the court in the Act.

112 See FCIA $\S 403$ (d), 96 Stat at 58 (cited in note 85).

113 See 28 USC \$ 1295(a)(3) (1988).

114757 F2d 247, 252 (Fed Cir 1985).

115 Id at 251-52. The court reasoned that because the FCIA required the Court of Federal Claims to determine EAJA fee applications that were pending at the time of the enactment of the FCIA, see FCIA § 403(d), 96 Stat at 58, Congress must have intended that the new Article I Court of Federal Claims have EAJA jurisdiction.

$116757 \mathrm{~F} 2 \mathrm{~d}$ at 251. 
ed States," despite the Eleventh Circuit's unpersuasive argument in Davis limiting Essex Electro's reasoning to its facts. ${ }^{117}$

\section{B. The Tax Court}

The Tax Court is an Article I court that adjudicates matters arising under federal tax law. ${ }^{118}$ Its decisions are appealable to the courts of appeals. ${ }^{119}$ Few cases before the Tax Court have involved the EAJA, because the window allowing applications for fees under the EAJA in tax cases closed on February 28, 1983. Congress amended the EAJA to provide that 26 USC $\S 7430$, which permits fee shifting, governs in tax cases brought on or after March 1, $1983 .{ }^{120}$

The leading Tax Court case dealing with the EAJA is McQuiston $v$ Commissioner. ${ }^{121}$ After prevailing against the IRS in a dispute over tax computation, McQuiston filed for attorneys' fees under the EAJA. The Tax Court denied McQuiston's application, holding that it lacked EAJA jurisdiction. ${ }^{122}$ McQuiston relied on a 1976 decision, Sharon $v$ Commissioner, which held that the only courts able to award costs under 2412(a) were "courts of the United States" as defined in 28 USC $\S 451$, which did not include the Article I Tax Court. ${ }^{123}$ Sharon was decided prior to the enactment of $\S 2412(\mathrm{~b})$ and (d); at that time, only costs, not attorneys' fees, could be taxed against the government. ${ }^{124}$ Sharon's argument is very similar to the Davis argument: Because $\S 2412$ (a) states that the costs which may be taxed against the government are listed in 28 USC $\S 1920$, and $\S 1920$ refers to a "court of the United States," only a court of the United States may award costs. This excludes-by the definition in $\S$ 451-Article I courts, including the Tax Court. ${ }^{125}$ McQuiston, relying on Sharon, held that the Tax Court did not have the statutory authority under the EAJA to shift attorneys' fees any more than to shift costs. ${ }^{126}$

${ }^{117}$ See text accompanying notes 84-91.

118 See 26 USC $\$ \$ 7441,7442$ (1988).

119 See 26 USC $\$ 7482$ (1988).

120 See note 94 .

12178 Tax Ct 807 (1982), aff'd 711 F2d 1064 (9th Cir 1983). See Note, Attorney's Fees in Tax Cases After the Tax Equity and Fiscal Responsibility Act of 1982, 36 Tax Lawyer $123,144-47$ (1982).

12278 Tax Ct at 812.

${ }^{123} 66$ Tax Ct 515, 533-34 (1976), aff'd 591 F2d 1273 (9th Cir 1978).

124 The government was liable for fees only where it had made an explicit waiver of its immunity. See Ruckelshaus v Sierra Club, 463 US 680, 685 (1983).

${ }^{125} 66 \mathrm{Tax} \mathrm{Ct}$ at $533-34$.

${ }^{128} 78 \mathrm{Tax}$ Ct at 811-12. McQuiston assumed that $\S 451$, defining "court of the United 
However, in Key Buick $v$ Commissioner, the Fifth Circuit rejected the Tax Court's conclusion that it was without power to assess costs. ${ }^{127}$ At issue was the fee-shifting authority of the Tax Court under the Civil Rights Attorneys' Fees Awards Act, 42 USC $\S 1988$, passed by Congress in response to Alyeska. ${ }^{128}$ The Fifth Circuit affirmed the Tax Court's holding that the taxpayer is only entitled to attorneys' fees under $\S 1988$ when he has been a defendant. ${ }^{129}$ However, the Fifth Circuit rejected, in dictum, the Tax Court's further conclusion that it was wholly without power to award costs: ${ }^{130}$ "We are not in accord ... with the conclusion of the Tax Court that it may never award attorneys' fees under any circumstances." ${ }^{131}$

Key Buick's analysis suggests that McQuiston's reliance on Sharon was misplaced. However, the question is now moot because all cases before the Tax Court now fall under 26 USC § 7430, not under the EAJA. Thus the Tax Court no longer has EAJA jurisdiction, and McQuiston is an outdated decision. ${ }^{132}$

\section{The Court of Military Appeals}

The Court of Military Appeals is an Article I court that reviews court-martial convictions in the armed services. ${ }^{133} \mathrm{Be}$ cause it is a criminal court, EA.JA questions (which are civil by definition) rarely come before it. However, in Navy-Marine Corps Court of Military Review $v$ Cheney, the Court of Military Appeals held that it had EAJA jurisdiction, though it ultimately refused to grant fees because the proceeding below had not been a true civil proceeding. ${ }^{134}$ The court rejected the Bowen arguments about congressional intent, holding instead that the plain language of the term "court" covered the Article I Court of Military Appeals. ${ }^{135}$

States," applies to every mention of "court" in Title 28. This is, as we have seen, overbroad.

227613 F2d 1306, 1309 (5th Cir 1980).

128 See text accompanying notes 23-25.

129613 F2d at 1309.

${ }^{130}$ The Tax Court's conclusion was, like McQuiston, in reliance on Sharon. See Key Buick v Commissioner, 68 Tax Ct 178, 179 (1977).

131613 F2d at 1309. See Note, 36 Tax Lawyer at 133-34, 146 (cited in note 121).

132 Bowen, on which the Eleventh Circuit relied in rejecting bankruptcy courts' EAJA jurisdiction, also dealt with Tax Court EAJA jurisdiction. See 706 F2d at 1088.

133 See 10 USC $\$ 867$ (1988).

13429 Military J 98, 103-04 (Ct Mil App 1989).

135 Id at 102-03. 
D. The Court of Veterans Appeals

The Court of Veterans Appeals is an Article I court with exclusive jurisdiction to review decisions of the Board of Veterans Appeals. ${ }^{136}$ Its decisions are appealable to the Federal Circuit and, subsequently, to the Supreme Court. ${ }^{137}$

In Jones $v$ Derwinski, the Court of Veterans Appeals held that it lacked EAJA jurisdiction. ${ }^{138}$ First, it concluded that the Supreme Court's Ardestani decision controlled its interpretation of the EAJA, in that any statutory ambiguity in the EAJA must be strictly construed in favor of the government. ${ }^{139}$ After examining the legislative history and various subsequent amendments of the EAJA, the court concluded that substantial ambiguity existed over whether it had fee-shifting jurisdiction. ${ }^{140}$ Furthermore, the split between the Eleventh and Tenth Circuits on whether Article I courts have EAJA jurisdiction magnified this ambiguity. Ardestani demanded that this ambiguity keep EAJA jurisdiction within the strictest possible confines. ${ }^{141}$

Jones misconstrues Ardestani. According to Jones, it was in response to statutory ambiguity that Ardestani applied the principle that waivers of sovereign immunity must be strictly construed. ${ }^{142}$ Ardestani, however, used the strict construction principle not to resolve an ambiguity, but to justify adherence to clear statutory language in the face of countervailing policy considerations. ${ }^{143}$ When the EAJA's language suggests that fee shifting is not allowed in a given context, but its purposes point the other way, the principle that waivers of sovereign immunity are to be strictly construed tips the balance in favor of prohibiting fee awards. Jones's use of the strict construction principle does not accord with Ardestani.

Congress reacted with vigorous displeasure to Jones. By the end of the same year, 1992, Congress had amended the EAJA to explicitly make clear that the Court of Veterans Appeals could shift fees under the statute. ${ }^{144}$ The legislative history of this

\footnotetext{
${ }^{136}$ See 38 USC $\S \S 4051,4052$ (1988).

13738 USC $\$ 4092(c)(1988)$.

1382 Vet App 231 (Ct Vet App 1992), vacated 985 F2d 582 (Fed Cir 1992),

1392 Vet App at 232-33, discussing Ardestani v INS, 112 S Ct 515 (1991).

1002 Vet App at 233.

161 Id at 233-34.

142 Id at 233.

${ }_{143}$ See Ardestani, 112 S Ct at 520.

144 See Federal Courts Administration Act $\S 506$, Pub L No 102-572, 106 Stat at 4513, codified at 28 USC $2412(d)(2)(F)$ (1988 \& Supp 1992). In response, the Federal Circuit
} 
amendment makes clear that Congress considers the EAJA to extend beyond Article III courts. "It is not the intent of the committee, by specifying the Court of Veterans Appeals, to exclude any other [non-Article III] courts having jurisdiction of an action from qualifying as a "court' under EAJA."145 Furthermore, the amendment "clarifies that [the EAJA] applies to the Court of Veterans Appeals." 146 The use of the term "clarify" shows that Congress considered the EAJA to have always included the Court of Veterans Appeals, and thus implicitly other parallel Article I courts as well.

\section{E. Bankruptcy Courts and Their 26 USC $\S 7430$ Jurisdiction}

Examining bankruptcy court fee-shifting powers under the fee-shifting provision of the Tax Code also sheds light on the question of whether bankruptcy courts have fee-shifting power under the EAJA. In the Internal Revenue Code, 26 USC $\S 7430$ contains fee-shifting provisions essentially identical to the EAJA, preempting the use of the EAJA in tax-related cases. ${ }^{147}$ It would be incongruous for Article I bankruptcy courts to be able to shift fees under $\S 7430$, which was designed to parallel the EAJA, but not to be able to shift fees under the EAJA.

Section 7430 confers fee-shifting authority on "court[s] of the United States (including the United States Tax Court and the United States Claims Court)." ${ }^{148}$ Relying on the EAJA-driven precedents of Davis and Bowen, the Eleventh Circuit held in In re Brickell that bankruptcy courts had no 26 USC $\S 7430$ jurisdiction. ${ }^{149}$ As already discussed, Brickell is an unpersuasive opinion. ${ }^{150}$ It glibly transposed Title 28's definition of "court of the United States," explicitly limited to that title, into Title 26 and concluded that because bankruptcy courts are clearly not "courts of the United States" under the Title 28 definition, they have no $\S 7430$ jurisdiction.

vacated Jones without opinion. See 985 F2d 582.

14 Federal Courts Study Committee Implementation Act, S Rep No 102-342, 102d Cong, 2d Sess 39-40 (1992).

${ }_{146}$ Federal Courts Administration Act of 1992, HR Rep No 102-1006, 102d Cong, 2d Sess 25.

${ }^{147}$ The EAJA itself originally covered tax cases, but Congress removed them in 1982 . See note 94 .

${ }_{148} 26$ USC $\S 7430(c)(6)(1988)$.

149922 F2d 696, 701 (11th Cir 1991).

150 See text accompanying notes 93-100. 
In contrast to Brickell, several bankruptcy courts have either reasoned or assumed that they have authority to award fees under $\S 7430 .{ }^{151}$ The leading case is In re Chambers, which held that for purposes of $\S 7430$, a bankruptcy court is a "court of the United States." ${ }^{.152}$ In Chambers's view, the additional phrase in $\$ 7430$, "including the Tax Court and the United States Claims Court," does not limit jurisdiction to those courts, because the specific courts are simply mentioned as illustrations, not limitations. ${ }^{153}$

Chambers uses an additional intriguing argument not used by any other court in the EAJA context. A bankruptcy court is a "court of the United States" for both EAJA and $\S 7430$ purposes because it is a dependent adjunct of a district court, which is undoubtedly a court of the United States. ${ }^{154}$ Chambers specifically rejected Brickell's interpretation as "unduly restrictive."1155

This review of the experience of several other Article I courts, as well as the experience of the bankruptcy courts in awarding fees under 26 USC $\$ 7430$, reveals, if not a unanimous result, at least a consistent trend in the direction of allowing fee shifting. Courts should take heed and, unless and until Congress explicitly modifies the EAJA, ensure that bankruptcy courts can and do use the EAJA for its intended purposes.

\section{WHY BANKRUPTCY COURTS CAN SHIFT FEES UNDER THE EAJA}

Bankruptcy courts should have the power to shift attorneys' fees under the EAJA. Both the Ardestani principles of EAJA interpretation, as well as a careful examination of statutory language and legislative history, support this conclusion.

\section{A. Ardestani's Support of the Authority of Bankruptcy Courts Under the EAJA}

Ardestani has muddied the waters of EAJA interpretation and, if Jones is any indication, promises to continue to do so. Although Ardestani emphasizes that courts should not expand the

${ }^{151}$ See In re Olson, 100 Bankr 458 (Bankr N D Iowa 1989); In re Graham, 106 Bankr 692 (Bankr D Colo 1989); In re Kiker, 98 Bankr 103 (Bankr N D Ga 1988).

${ }_{132} 131$ Bankr 818, 824 (Bankr N D Ill 1991), aff'd in part, rev'd in part on other grounds, 140 Bankr 233 (N D Ill 1992).

153 See 131 Bankr at 824.

154 Id at 824-25.

iss Id. 
EAJA's waiver of sovereign immunity, it does not dictate that the EAJA be construed to deny fee-shifting power to bankruptcy courts.

For the purposes of this Comment, the essential principle of Ardestani is that courts must not mutate clear EAJA language. The Court found that the language of the EAJA provision at issue in Ardestani was unambiguous, ${ }^{156}$ and that "any ambiguities in the legislative history [were] insufficient to undercut the ordinary understanding of the statutory language." ${ }^{167}$ The Court concluded that the clear language, "coupled with the strict construction of waivers of sovereign immunity," meant that the INS could not award fees in administrative deportation proceedings. ${ }^{158}$ The basis of the Court's holding was the plain language determination-the waiver question merely "reinforced" its conclusion on those grounds. ${ }^{169}$

Bankruptcy court EAJA jurisdiction is different from the question in Ardestani. In the bankruptcy court cases, courts have held that the EAJA's plain language is either ambiguous or clearly in favor of shifting fees. ${ }^{160}$ The essential Ardestani premise, that the language in question clearly opposes shifting fees, is therefore not present in the context of bankruptcy courts. Ardestani noted that "once Congress has waived sovereign immunity over certain subject matter, the Court should be careful not to 'assume the authority to narrow the waiver that Congress intended." 161 In the EAJA context, Congress has clearly waived sovereign immunity over the area of fee shifting against the government, and courts should not try to narrow the intended waiver. ${ }^{162}$ Ardestani, properly read, thus supports the contention that bankruptcy courts have EAJA jurisdiction, because both the statutory language and the waiver of sovereign immunity are clear.

${ }^{156}$ Ardestani, $112 \mathrm{~S}$ Ct at 519. The Court considered whether an administrative deportation hearing was an "adversary adjudication" for purposes of Title 5 of the EAJA.

157 Id at 520.

158 Id at 521.

159 Id at 520.

${ }_{160}$ Compare O'Connor $v$ United States Department of Energy, 942 F2d 771, 773 (10th Cir 1991) (language clear), with Bowen $v$ Commissioner of Internal Revenue, 706 F2d 1087, 1088 (11th Cir 1983) (language ambiguous).

161112 S Ct at 520, quoting United States $v$ Kubrick, 444 US 111, 118 (1979).

162 Furthermore, '[t]he 'strong presumption' that the plain language of the statute expresses congressional intent is rebutted only in 'rare and exceptional circumstances,' when a contrary legislative intent is clearly expressed.” Ardestani, 112 S Ct at 520. 


\section{B. Interpretation of Congressional Action and Inaction}

Several interpretive arguments suggest that bankruptcy courts should be able to shift fees under the EAJA. The most natural reading of "court" is an inclusive reading. Any ordinary reading would not limit the term to Article III courts. Furthermore, the EAJA's phrase "any court having jurisdiction of that action" implies on its face that any court competent to adjudicate the matter has fee-shifting jurisdiction as well.

Standard principles of statutory interpretation lead to the same conclusion. It imputes ignorant confusion to Congress to maintain that, after using "court of the United States" throughout Title 28, it intended its references to "a court" and "any court" in the EAJA to be synonymous with "court of the United States." III courts, it could easily have done so by simply using the phrase "court of the United States." Given that "court of the United States" has an explicitly defined meaning in Title 28, Congress's failure to use that term strongly suggests that it meant to refer to a different group of courts. Such a conclusion is perfectly reasonable, especially considered in light of the overall goals of the EAJA. Congress wanted the EAJA to be broadly applicable, and it expressed this intent in sweeping language: "For many citizens, the costs of securing vindication of their rights and the inability to recover attorney fees preclude resort to the adjudicatory process."164 Fee shifting allows meritorious cases to come forward. A forced, narrow reading of the EAJA frustrates these explicit goals, which suggest Congress wanted "court" to include all tribunals within the EAJA's scope.

Some may respond that application of the familiar canon of interpretation expressio unius est exclusio alterius ${ }^{165}$ leads to the conclusion that Congress's amending of the EAJA to include the Claims Court and the Court of Veterans Affairs evinces Congress's intent to exclude bankruptcy courts. However, clear

${ }^{163}$ In 1978 Congress modified the Title 28 definition "court of the United States" to explicitly include bankruptcy courts. The Supreme Court's striking down of Congress's attempt to reform the Bankruptcy Code in Northern Pipeline Construction Co. v Marathon Pipe Line Co., 458 US 50, 87 (1982), voided this amendment. See Anthony Michael Sabino, "And Unequal Justice for All"-Bankruptcy Court Jurisdiction Under the Equal Access to Justice Act, 22 Memphis St U L Rev 453, 461-62 (1992).

164 HR Rep No 96-1418 at 9, reprinted in 1980 USCCAN 4984, 4988 (cited in note 28).

165 "Mention of one thing implies exclusion of another. When certain persons or things are specified in a law ... an intention to exclude all others from its operation may be inferred." Black's Law Dictionary 581 (West, 6th ed 1990). 
legislative history forecloses this otherwise plausible counterargument. When amending the EAJA, Congress made clear its intent that its actions not be construed as a limitation on which courts were able to shift fees. Given this legislative history, it is difficult to conclude that Congress meant to deny EAJA jurisdiction to bankruptcy courts.

Careful examination of the circumstances surrounding congressional action shows Congress's rationality in not expressly listing bankruptcy courts. Congress specifically included the Claims Court in the EAJA in 1985 because a rift had developed in judicial authority. Further, at the time of the Claims Court amendment, no court had refused EAJA jurisdiction to bankruptcy courts. On the contrary, at least two courts had assumed that bankruptcy courts did have EAJA jurisdiction. If Congress knew about those decisions, it likely decided that there was no need to amend the EAJA simply to affirm the existing case law. If it did not know about the decisions, there was similarly no reason for Congress to have specifically included bankruptcy courts in the EAJA, in the absence of conflict over the issue, just as there was no reason to include any other Article I court.

\section{CONCLUSION}

Those courts that deny fee-shifting powers to bankruptcy courts ultimately fail to persuade. They stretch too far by departing from the ordinary meaning of statutory terms, and relying on snippets of legislative history that stand in opposition to the EAJA's overall goals. On the other hand, the arguments of those courts that recognize bankruptcy court authority to shift fees under the EAJA are very convincing. They harmonize the plain language of the statute with the undisputed intent of the EAJA, and by doing so reach an equitable result that succeeds in implementing congressional goals.

Recognizing that bankruptcy courts can shift fees under the EAJA fills an important gap in the law. Courts can fulfill EAJA's goals in bankruptcy proceedings without waiting for Congress to explicitly amend EAJA. The legitimacy of this approach is buttressed by Supreme Court precedent, the authority of several courts, and careful examinations of statutory interpretation and congressional action. This approach is not a bold step cutting against the grain of rationality to achieve justice; rather, it achieves justice by comporting with rationality. 